\title{
The Immunological Effect of Photopheresis in Children with Newly Diagnosed Type 1 Diabetes
}

\author{
MARIA KARLSSON FARESJÖ, JAN ERNERUDH, GÖSTA BERLIN, JORGE GARCIA, \\ AND JOHNNY LUDVIGSSON \\ Division of Pediatrics and Diabetes Research Centre [M.K.F., J.G., J.L.], Division of Clinical \\ Immunology [J.E.], Division of Transfusion Medicine [G.B.], Department of Molecular and Clinical \\ Medicine, Faculty of Health Sciences, Linköping University, S-581 85 Linköping, Sweden
}

\begin{abstract}
ABST
Photopheresis has been claimed to have immune-modulating
effects, but the mechanisms of action are unknown. This study
investigated the immune effect of photopheresis in children with
type 1 diabetes, with a focus on the balance of Th1- and Th2-like
cytokines. Ten children with newly diagnosed type 1 diabetes
(10-17 y) were treated with five double treatments of photo-
pheresis and 10 children matched for disease, age, and gender
were given placebo tablets and sham pheresis. Expression of
IFN- $\gamma$ and IL-4 mRNA was determined by real-time reverse-
transcriptase polymerase chain reaction (RT-PCR) and secretion
of IFN- $\gamma$, IL-10, and IL-13 in cell-culture supernatants by ELISA
after stimulation with glutamic acid decarboxylase (GAD 65 ) (a.a.
247-279), the ABBOS peptide (a.a. 152-169), insulin, phytohe-
magglutinin (PHA), and keyhole limpet hemocyanin (KLH).
Photopheresis changed antigen-stimulated immune balance in
line with a Th2-like shift. Thus, the ratio of IFN- $\gamma / \mathrm{IL}-4$ mRNA
\end{abstract}
Type 1 diabetes, characterized as an autoimmune disease, has been shown to be transferable by $\mathrm{CD} 4^{+} \mathrm{T}$ cells expressing a Th1-like cytokine profile in neonatal NOD mice (1). Th1 responses, of which IFN- $\gamma$ is a signature cytokine (2,3), stimulate phagocytose-dependent cellular immune responses that are detrimental in several organ-specific autoimmune diseases $(4,5)$ as well as in transplantation reactions (6). Th1-responses are counteracted by Th2 cytokines, including IL-4 and IL-13. IL-13, shown to be produced mainly by activated Th2-like lymphocytes and natural killer cells (7), shows functions similar to those of IL-4 (8). In addition, IL-10 is a potent antiinflammatory cytokine, with down-regulating effects on Th1

Received August 30, 2004; accepted January 4, 2005

Correspondence: Maria Karlsson Faresjö, Ph.D., Clinical Research Center, Division of Pediatrics, Faculty of Health Sciences, S-581 85 Linköping, Sweden: e-mail: maria.faresjo@imk.liu.se

Supported by the Söderberg Foundation, Swedish Medical Research Council (K9972X-11242-05A), Novo Nordisk Research Found, JDF-Wallenberg (K98-99JD-12813 01A), Medical Research Found of the County of Östergötland, Samaritens' Foundation, The Swedish Diabetes Foundation, The Swedish Child Diabetes Foundation (Barndiabetesfonden), and the Queen Silvia's Jubilee Foundation.

DOI: 10.1203/01.pdr.0000176906.42001.c3 expression after in vitro stimulation with a peptide of the autoantigen $\mathrm{GAD}_{65}$ was reduced after treatment in the photopheresis group. The IFN- $\gamma / \mathrm{IL}-4$ mRNA expression ratio after in vitro stimulation with insulin was also lower in children treated with photopheresis compared with the placebo group. Photopheresis has an immune-modulating effect in children with type 1 diabetes, causing a Th2-like deviation. (Pediatr Res 58: 459-466, 2005)
Abbreviations
GAD $_{65}$, glutamic acid decarboxylase 65
ICA, islet cell antibody
KLH, keyhole limpet hemocyanin
MOP, methoxypsoralen
PBMCs, peripheral blood mononuclear cells
PHA, phytohemagglutinin

responses (9). Evidence that $\beta$-cell destruction in type 1 diabetes has a Th1-like origin is accumulating, and it has also been suggested that Th2-like lymphocytes are protective for the disease $(10,11)$.

It has been claimed that photopheresis has immunemodulating effects (12) and is a treatment of great interest for several immunological diseases including cutaneous T-cell lymphoma $(13,14)$, acute and chronic graft versus host disease (15), cardiac allografts rejection (16), rheumatoid arthritis (RA) (17), systemic lupus erythematosus (SLE) (18) and psoriatic arthritis (19). However, the mechanisms of action are not well understood. It is known that 8-MOP on activation by UVA light, interacts with bases of DNA (20) and binds to sites on the cell surface and/or in the cytoplasm of the target cells (21). It has also been suggested that photopheresis is effective through dendritic-cell/T-cell interactions in stimulating T-cell responses or down-regulating a preexisting $\mathrm{T}$-cell response $(22,23)$. In a photopheresis trial of children with newly diagnosed type 1 diabetes, we noticed a moderate clinical effect with lower insulin requirement and slightly better residual insulin secretion in the treatment group (24). The double-blind, 
placebo-controlled (placebo tablets and sham pheresis), randomized design allowed us to investigate short-term effects on the immune system and dissect them from the natural course or placebo effect. Our focus was the balance between Th1- and Th2-like cytokines, and we hypothesized that photopheresis could induce a shift in the balance between Th1 and Th2 cytokines.

\section{METHODS}

Treatment with photopheresis. Twenty children with newly diagnosed type 1 diabetes (10-17 y, 90\% carrying the HLA-type DR3/4), a random subsample of a larger study (24), were included in the present detailed study on autoantigen-induced cytokine profiles. Ten children were randomly selected from the group of active treatment of photopheresis, consisting of an oral dose of 8 -MOP and a subsequent apheresis procedure. Plasma and buffy coat cell solution concentrations of 8-MOP were followed (25). The mean plasma concentration was $320 \mathrm{ng} / \mathrm{mL}$ (range 101-466) and the mean 8-MOP concentration of the cell solution during irradiation was $106 \mathrm{ng} / \mathrm{mL}$ (range 30-186). The buffy coat cells were then exposed to UVA light $\left(2 \mathrm{~J} / \mathrm{cm}^{2}\right)$ for $90 \mathrm{~min}$ and returned to the patient's circulation. The control group, comprising 10 children with type 1 diabetes, matched by age and gender, received placebo tablets and sham treatment (similar procedure but without passage of blood cells through the photopheresis machine). The apheresis procedure (active photopheresis or sham pheresis) was administrated on two consecutive days (double treatment). The first treatment was given approximately 5-6 d after the diagnosis of type 1 diabetes and then repeated after 14, 28, and $42 \mathrm{~d}$ and 3 mo.

Peripheral blood mononuclear cells. Peripheral blood was collected right before start of each treatment at d 1, 14, and 28 and finally after 3 mo, the first sample thus representing status before any treatment (S1), and the remaining samples representing status after 1 (S2), 2 (S3), and 4 (S4) double-treatment procedures, respectively. PBMCs were isolated by Ficoll Paque density gradient centrifugation (Pharmacia, Biotech, Sollentuna, Sweden) from sodium heparinized venous blood samples. As blood samples were taken at different occasions, PBMCs were cryopreserved in liquid nitrogen until use.

Peptides and antigens. The synthetic peptide of human $\mathrm{GAD}_{65}$ ) (a.a. 247-279) and the synthetic milk-derived BSA-peptide ABBOS (a.a. 152-169) (26) (both purchased from the Department of Medical and Physiologic Chemistry, University of Uppsala, Sweden), insulin (Actrapid, Novo Nordisk, Bagsvaerd, Denmark), KLH (Calbiochem, Lab Kemi, Stockholm, Sweden), and PHA (Sigma Chemical Co., Stockholm, Sweden) were used for stimulation of PBMCs.

PBMCs and stimulation procedures. Frozen mononuclear cells were thawed, directly from $-196^{\circ} \mathrm{C}$ to $+37^{\circ} \mathrm{C}$, in a water bath during addition of RPMI-1640 supplemented with $10 \%$ FCS; $1 \times 10^{6}$ PBMCs (viability approximately $90 \%$ for each population) were diluted in $500 \mu \mathrm{L}$ AIM V serum-free medium (GIBCO, Täby, Sweden) supplemented with $2 \mathrm{mM}$ L-glutamine, 50 $\mu \mathrm{g} / \mathrm{L}$ streptomycin sulfate, $10 \mu \mathrm{g} / \mathrm{L}$ gentamicin sulfate and $2 \times 10^{-5} \mathrm{M}$ 2-mercaptoethanol (Sigma Chemical Co.). Then $1 \times 10^{6}$ PBMCs were stimulated with $\mathrm{GAD}_{65}$ (a.a. 247-279), the ABBOS peptide, PHA or KLH, all at a concentration of $5 \mu \mathrm{g} / \mathrm{mL}$, or with insulin at a concentration of $50 \mu \mathrm{g} / \mathrm{mL}$ $(27,28)$ for $48 \mathrm{~h}$ at $37^{\circ} \mathrm{C}$ in $5 \% \mathrm{CO}_{2}$ for further analysis of the expression of cytokine-specific mRNA.

For analysis of cytokines in the cell-culture supernatants, $1 \times 10^{6} \mathrm{PBMCs}$ were stimulated with the same concentration of PHA or KLH, whereas 50 $\mu \mathrm{g} / \mathrm{mL}$ was used for $\mathrm{GAD}_{65}$ (a.a. 247-279) and the ABBOS peptide (29) and insulin was used at a concentration of $500 \mu \mathrm{g} / \mathrm{mL}$ for $96 \mathrm{~h}$ at $37^{\circ} \mathrm{C}$ in $5 \% \mathrm{CO}_{2}$. PBMCs, incubated without antigen but otherwise under the same conditions, were used for determination of spontaneous expression of mRNA and secretion of cytokines. In samples with a limited number of cells, the order of priority for stimulation with antigens was $\mathrm{GAD}_{65}$ (a.a. 247-279), the ABBOS peptide, insulin, PHA, and KLH.

RNA isolation, cDNA synthesis, and real-time RT-PCR. Total RNA was isolated from PBMCs as described previously (29). Using equal amounts of total RNA (7 ng/ $\mu \mathrm{L})$ from PBMCs stimulated under various conditions, mRNA was marked with complementary random hexamers and cDNA was synthesized as described elsewhere (29). PCR reaction mixture contained specific target primers and probes for IFN- $\gamma$, IL-4, and endogenous reference rRNA (TaqMan cytokine gene expression kit, Perkin Elmer). The reaction mixture was amplified with ABI Prism 7700 Sequence Detector (Perkin Elmer) for 40 cycles with an annealing temperature of $60^{\circ} \mathrm{C}$ for IL- 4 and IFN- $\gamma$ according to previous description (29). In all experiments, controls without template as well as control RNA (Perkin Elmer) were included.
Calculation of relative quantification values. The relative quantification values for the cytokine gene expression assays were calculated from the accurate $\mathrm{C}_{\mathrm{T}}$, according to the manufacturer's description (protocol $\mathrm{P} / \mathrm{N}$ 4304671, Perkin Elmer). The accurate $\mathrm{C}_{\mathrm{T}}$ represents the PCR cycle at which an increase in reporter fluorescence above a baseline signal can first be detected, obtained from both dye layers in the assay. $\mathrm{C}_{\mathrm{T}}$ value for rRNA (VIC) was subtracted from the specific cytokine $\mathrm{C}_{\mathrm{T}}$ value (FAM for IFN- $\gamma$ and IL-4) to calculate $\Delta-C_{T}$ for the calibrator and samples in each cytokine gene expression assay. $\Delta-\mathrm{C}_{\mathrm{T}}$ values for duplicate wells of the calibrator sample for each cytokine were averaged. The average delta (calibrator) value was subtracted from the $\Delta-\mathrm{C}_{\mathrm{T}}$ values of samples to calculate their $\Delta \Delta-\mathrm{C}_{\mathrm{T}}$ (sample) value. The $\Delta \Delta-\mathrm{C}_{\mathrm{T}}$ value for duplicate wells of each cytokine sample was averaged. This operation normalizes the number of target mRNA molecules to the number of rRNA molecules. Relative quantification values were obtained after calculating the 2-average $\Delta \Delta-\mathrm{C}_{\mathrm{T}}$.

ELISA. IFN- $\gamma$ at the level of protein was measured in cell-culture supernatant by ELISA (30) in microtiter wells (Costar 3690, Life Technologies, Stockholm, Sweden) coated with $2 \mu \mathrm{g} / \mathrm{mL}$ monoclonal mouse anti-human antibody (clone 2571811, R\&D Systems, Abingdon, U.K.) in coating buffer (CLB, Amsterdam, Netherlands) overnight at room temperature. Wells were blocked with $2 \%$ milk in PBS for $1 \mathrm{~h}$ at room temperature. Cell supernatants and standard (recombinant human IFN- $\gamma, \mathrm{R} \& \mathrm{D}$ ) were applied in duplicates and incubated for $1 \mathrm{~h}$ at room temperature. IFN- $\gamma$ was detected by $0.20 \mu \mathrm{g} / \mathrm{mL}$ goat anti-human biotinylated polyclonal antibody (R\&D) diluted in highperformance ELISA dilution buffer (CLB) for $1 \mathrm{~h}$ at room temperature and further incubated for $30 \mathrm{~min}$ at room temperature with horseradish peroxidaseconjugated to polystreptavidin $(0.1 \mu \mathrm{M}, \mathrm{CLB})$. A colored product was formed in proportion to the amount of IFN- $\gamma$, after incubation with $3,3^{\prime}, 5,5^{\prime}$ tetramethylbenzidine liquid substrate (Sigma Chemical Co.-Aldrich) for 30 min in the dark and thereafter with $1.8 \mathrm{M} \mathrm{H}_{2} \mathrm{SO}_{4}$ to stop the reaction. The sensitivity for IFN- $\gamma$ was $12 \mathrm{pg} / \mathrm{mL}$, according to the manufacturer.

IL-10 and IL-13 were measured by commercially available ELISA (CLB Pelikine Compact, Amsterdam, The Netherlands). In brief, microtiter wells (Costar 3690, Life Technologies, Stockholm, Sweden) were coated with a monoclonal anti-human antibody in coating buffer overnight at room temperature, whereas nonbound material was removed by washing. Wells were blocked with 5\% milk in PBS for $1 \mathrm{~h}$ at room temperature. Cell supernatants and standards (recombinant human IL-10/IL-13) were applied in duplicates and incubated for $1 \mathrm{~h}$ at room temperature. Cytokine was detected by antihuman biotinylated polyclonal antibody diluted in high-performance ELISA dilution buffer for $1 \mathrm{~h}$ at room temperature and further incubated for $30 \mathrm{~min}$ at room temperature with horseradish peroxidase-conjugated to polystreptavidin. The sensitivity was $2.35 \mathrm{pg} / \mathrm{mL}$ for IL-10 and $1.0 \mathrm{pg} / \mathrm{mL}$ for IL-13, according to the manufacturer.

Antigen-induced cytokine response was presented as $\mathrm{pg} / \mathrm{mL}$ after subtraction of spontaneously secreted cytokine from PBMCs incubated without antigen but otherwise cultured under the same conditions.

C peptide. C peptide was determined with a RIA technique based on the original assay developed by Heding (31). The detection limit for the assay is $0.03 \mathrm{nmol} / \mathrm{L}$, and our local reference value among fasting healthy children and adolescents is $0.18-0.63 \mathrm{nmol} / \mathrm{L}(32)$.

ICAs. ICA was detected with immunofluorescence on human pancreas sections according to Bottazzo et al. (33). A monospecific anti-IgG, conjugated with fluorescein-isothiocyanate was used for detection. Our method was standardized according to International Juvenile Diabetes Foundation (IJDF) standards for ICA determination. Our laboratory has participated in an international ICA workshop, with a specificity as well as sensitivity of $100 \%$.

GAD autoantibodies (GADAs). GADAs were determined according to Grubin et al. (34) and Petersen et al. (35), using recombinant human ${ }^{35} \mathrm{~S}$ $\mathrm{GAD}_{65}$ as tracer according to Falorini et al. (36). Serum was immunoprecipitated with human ${ }^{35} \mathrm{~S}_{-} \mathrm{GAD}_{65}$ in duplicates. Included in each assay was one strongly positive control (international JDF standard) and three negative samples (sera from three healthy controls). Our laboratory participated in the second GADA proficiency test 1996 and reached a sensitivity and a specificity of $100 \%$. The cutoff level for positivity was mean +3 SD for healthy controls $(=0.055)$.

Insulin antibodies (IAs). IAs were detected with a radioligand competition assay according to Palmer et al. (37). Included in each assay were a positive control (pool of sera from three IA-positive patients) and a negative control (with undetectable IA). Results were calculated as the difference between incubation with ${ }^{125} \mathrm{I}$-insulin and incubation with ${ }^{125} \mathrm{I}$-insulin and excess of unlabeled antigen. Cutoff was set at mean +2 SD for healthy controls $(=99$ $\mathrm{nU} / \mathrm{mL})$.

Statistics. Treatment versus placebo groups were compared by MannWhitney $U$ test and paired groups (pre- versus posttreatment) by Wilcoxon signed rank test. Three or more groups were compared with the Kruskal-Wallis test for unpaired observations. Spearman's rank correlation was used when 
comparing two variables nonparametrically. A probability level of $<0.05$ was considered to be statistically significant, whereas $p \leq 0.1$ was regarded as a tendency. Calculations were performed with a statistical package StatView 5.0.1 for Macintosh (Abacus Concepts Inc., Berkeley, CA)

Ethics. The study was approved by the Research Ethics Committee of the Faculty of Health Sciences, Linköping University, and all parents or responsible guardians gave their informed consent on behalf of the children.

\section{RESULTS}

Short-term immunological effects of photopheresis treatment. Photopheresis caused changes in the immune balance of children with type 1 diabetes in a number of parameters (Table $1 a, b)$. Spontaneously secreted IL-10 increased during the whole period of treatment $(p<0.05)$ (Table $1 b$ shows changes in cytokine profile within the group of children treated with photopheresis).

$\mathrm{GAD}_{65}$ peptide-induced expression of IFN- $\gamma$ mRNA decreased during treatment with photopheresis $(p<0.05)$ (Table $1 a)$. In contrast, IL-4 mRNA expression tended to increase during treatment with photopheresis $(p=0.07)$, although expression of IL-4 mRNA was lower in these children before treatment $(p<0.01)$ (Table $1 b)$. Thus, the ratio of expressed IFN- $\gamma / \mathrm{IL}-4$ mRNA decreased significantly among children treated with photopheresis $(p<0.01)$ (Fig. 1a), whereas the IFN- $\gamma / \mathrm{IL}-4$ mRNA ratio in fact increased in the sham pheresis group $(p<0.05)$ (Table $1 a$ and Fig. $1 b$ ).

In children treated with photopheresis, insulin-induced expression of IL-4 mRNA increased $(p<0.05)$ (Table $1 b)$ in relation to decreased IFN- $\gamma$ mRNA expression $(p=0.01)$ (Table $1 a$ ) at the end of treatment. Thus, the ratio of IFN- $\gamma /$ IL-4 mRNA decreased during active treatment $(p<0.01)$ (Fig. $2 a$ ). Insulin also decreased the secretion of IL-10 in children with type 1 diabetes during treatment with photopheresis $(p<$ 0.05) (Table 1b).

The only significant effect from in vitro stimulation with the ABBOS peptide was observed as an increased secretion of IFN- $\gamma$ in children treated with photopheresis $(p<0.05)$ (Table $1 a)$.

PHA always induced prominent mRNA expression and cytokine secretion. However, the expression of both IFN- $\gamma$ mRNA $(p<0.05)$ (Table $1 a)$ and IL-4 mRNA $(p<0.05)$ (Table $1 b$ ) decreased during photopheresis treatment. Thus, the ratio of PHA-induced IFN- $\gamma / \mathrm{IL}-4$ mRNA expression $(p=$ 0.01 ) (Table $1 a)$ as well as secretion of IL-10 $(p<0.05)$ (Table $1 b$ ), decreased after 3 mo of treatment with photopheresis.

Immunological effects in children treated with photopheresis compared with placebo-treated children. Spontaneous secretion of IFN- $\gamma$ tended to be lower after 2 wk of treatment in the photopheresis group compared with the placebo group $(p=$ $0.08)$. However, IFN- $\gamma$ secreted spontaneously and was higher in the actively treated group at 3 mo compared with the sham pheresis group $(p<0.05)$ (Table $1 a$, photopheresis versus placebo).

The $\mathrm{GAD}_{65}$ peptide-induced secretion of IFN- $\gamma$ tended to be lower among children treated with photopheresis when compared with the placebo group 1 mo after initial treatment $(p=$ 0.07). In contrast, $\mathrm{GAD}_{65}$ peptide-induced secretion of IL-13 was higher after 2 wk of treatment with photopheresis com- pared with the levels in the placebo group $(p<0.05)$ (Table $1 b)$.

The expression of IFN- $\gamma$ mRNA $(p<0.05)$ and secretion of IFN- $\gamma(p<0.05)$, after in vitro stimulation with insulin, was significantly lower in the photopheresis group compared with the placebo group after 3 mo of treatment (Table 1a). Thus, the ratio of IFN- $\gamma /$ IL- 4 mRNA was lower in children treated with photopheresis compared with children in the sham pheresis group after 3 mo ( $p=0.001)$ (Fig. $2 b)$.

Exposure to PHA, regardless of treatment, caused increased secretion of IFN- $\gamma$, which tended to be correlated with the expression of IFN- $\gamma$ mRNA during the first month of treatment $(\mathbf{r}=0.62, p=0.08)$. The expression of IFN- $\gamma$ mRNA $(p<$ $0.01)$ (Table $1 a)$ and IL-4 mRNA $(p<0.05)$ (Table $1 b$ ) was higher 2 wk after initial photopheresis treatment of the children with diabetes compared with the placebo group. In contrast, in the negative control, KLH did not cause any pronounced immune response in PBMCs from children with type 1 diabetes (data not shown). Further, the response from stimulation with the ABBOS peptide, both at the level of transcription and after translation into cytokines, did not differ between children treated with photopheresis or placebo.

Effect of photopheresis on $C$ peptide and antibodies. C peptide increased during the first 3 mo in all children regardless of treatment with photopheresis or placebo (Table 2). The level of islet cell antibodies (ICA) was significantly lower at onset and at 1 mo among children receiving photopheresis treatment compared with children treated with sham pheresis $(p<0.05)$ (Table 2, photopheresis versus placebo). The frequency of children positive for $\mathrm{GAD}_{65}$ autoantibodies (GADA) was equal in children treated with photopheresis or placebo (seven of 10 children in each group). The numbers of insulin antibody (IA)-positive children treated with photopheresis or placebo during the first 2 wk were seven of 10 and nine of 10 , respectively. Thereafter, all children regardless of treatment produced IAs and the concentration of IA increased at $3 \mathrm{mo}$ in children treated with either photopheresis or sham pheresis $(p$ $<0.05$ ) (Table 2, changes in secretion). At 3 mo, there was a positive correlation observed between the $\mathrm{GAD}_{65}$ peptideinduced ratio of IFN- $\gamma / \mathrm{IL}-4$ and GADA $(r=0.87, p=0.01)$ but an inverse correlation between insulin-induced IFN- $\gamma / \mathrm{IL}-4$ and IA $(r=-0.61, p=0.07)$.

\section{DISCUSSION}

We have previously reported that photopheresis has a slight short-term clinical effect on children with type 1 diabetes (24). Although there is little known of how photopheresis exerts its effects, we present cytokine data that give insight into immune mechanisms. The most prominent effects were found at the level of cytokine mRNA expression in the response against two putative autoantigens, a $\mathrm{GAD}_{65}$-derived peptide, and insulin. Children treated with photopheresis responded to $\mathrm{GAD}_{65}$ with decreased expression of IFN- $\gamma$ mRNA, in combination with increased expression of IL-4 mRNA. Thus, photopheresis induced a shift toward a Th2-like cytokine pattern. A Th2-like 


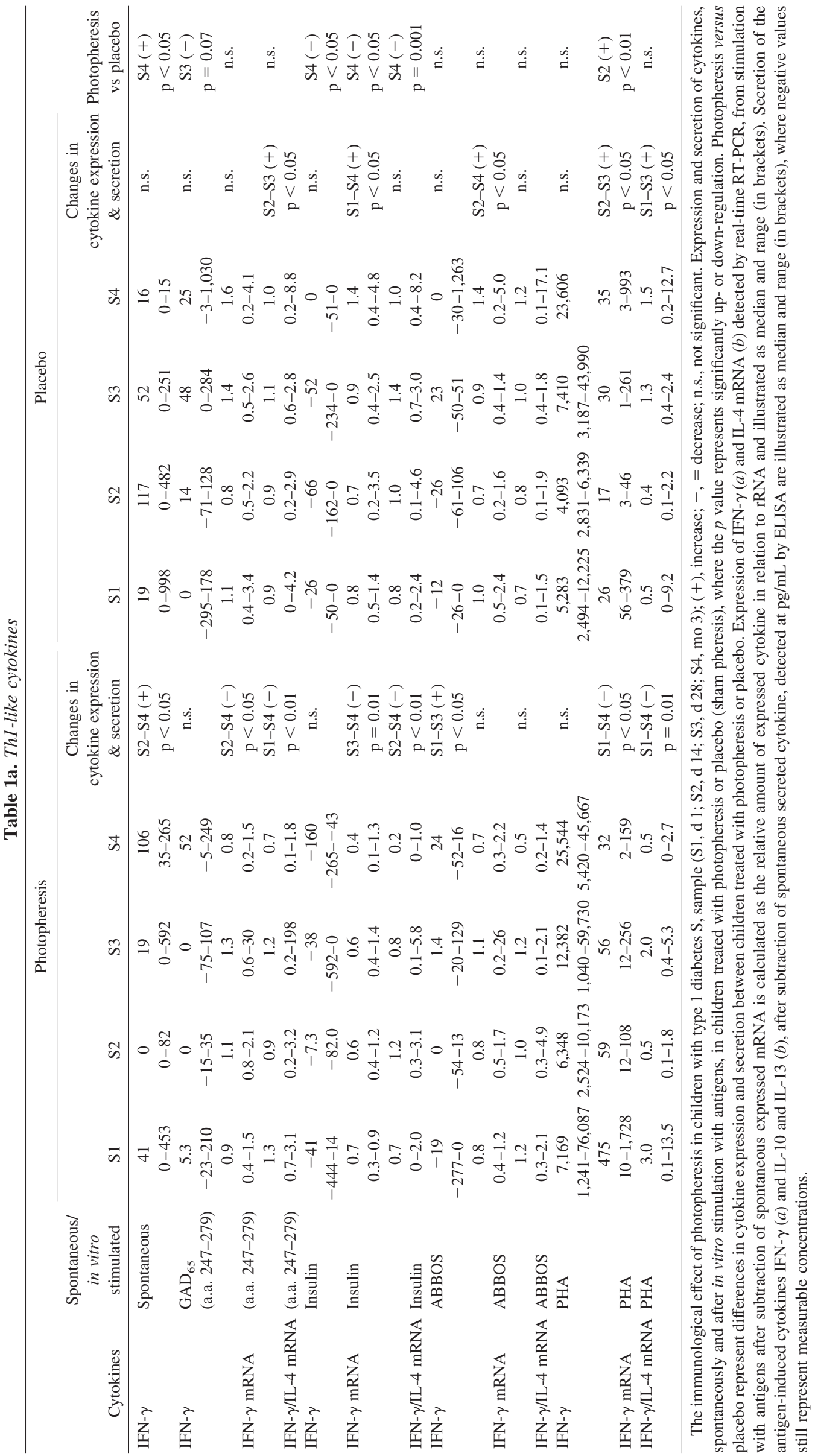




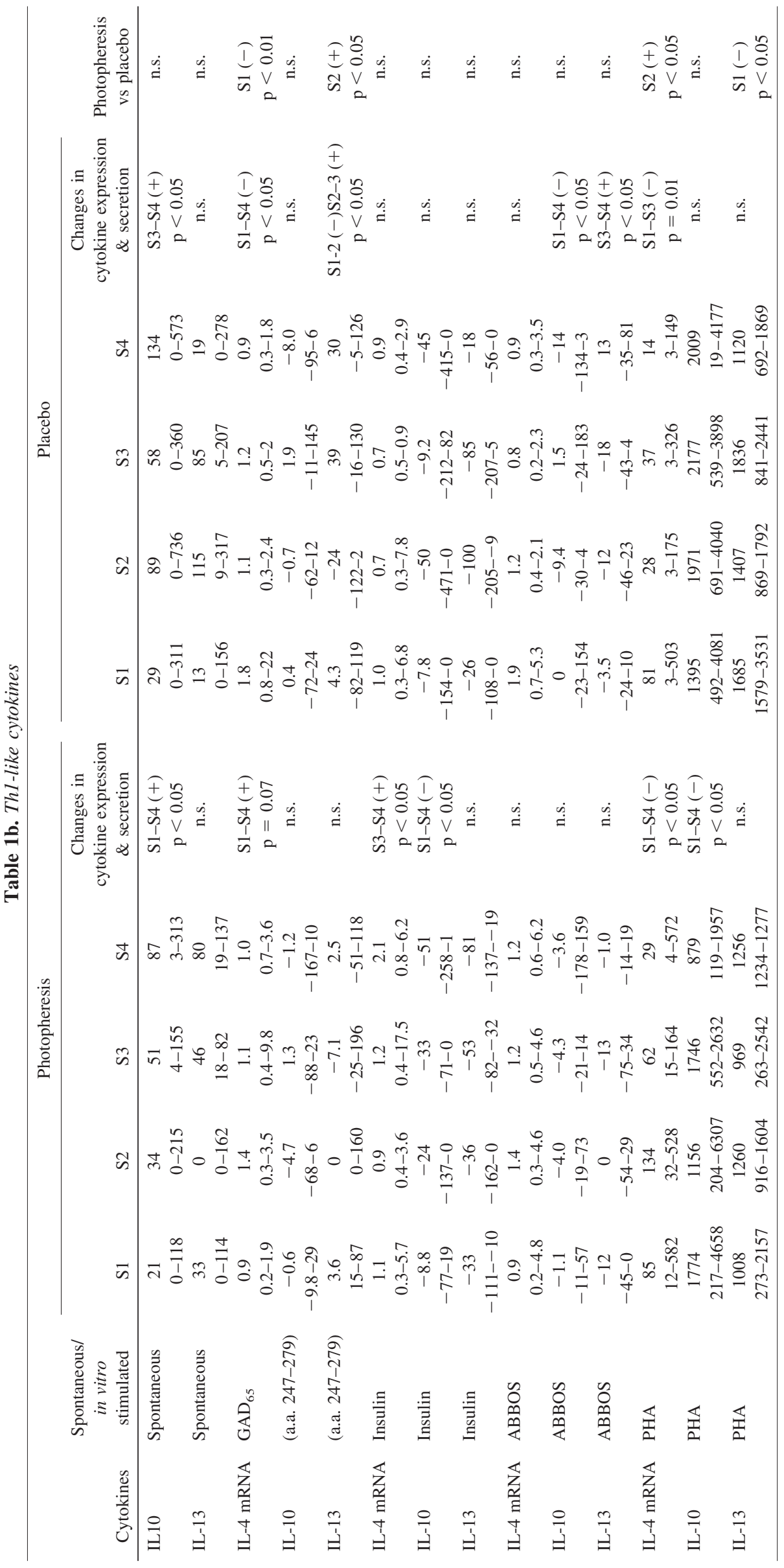



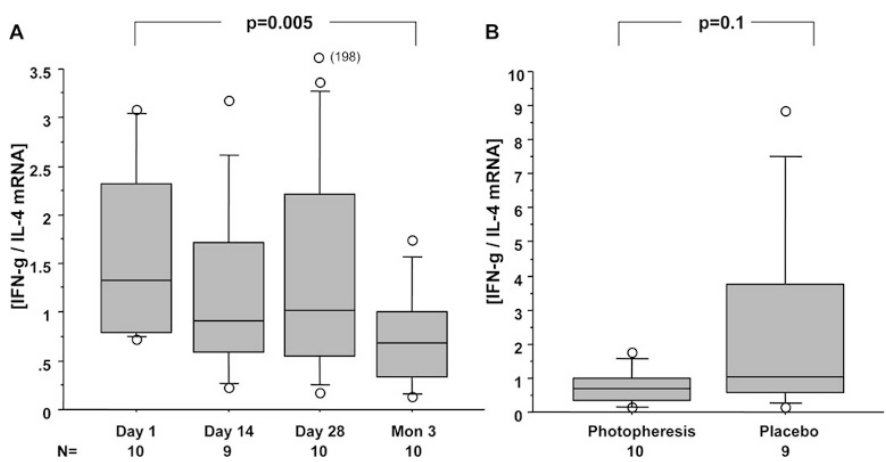

Figure 1. $\mathrm{GAD}_{65}$ (a.a. 247-279) induced IFN- $\gamma / \mathrm{IL}-4$ mRNA, expressed as a ratio, decreased in children with type 1 diabetes during treatment with photopheresis $(p=0.005)(a)$ and tended to be lower compared with children treated with sham pheresis after 3 mo $(p=0.1)(b)$. Illustrated by box plots (10th, 25th, 50th, 75th, and 90th centiles, and outliers are indicated).
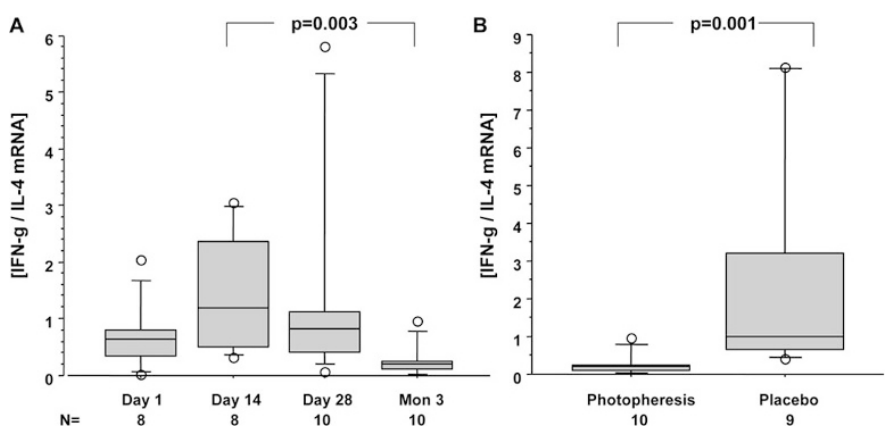

Figure 2. Children with type 1 diabetes treated with photopheresis responded with a decreased IFN- $\gamma /$ IL- 4 mRNA expression ratio to in vitro stimulation with insulin $(p=0.003)(a)$. The ratio was lower after 3 mo of treatment in the photopheresis group compared with the placebo group $(p=0.001)(\mathbf{b})$.

pattern, in the form of increased IL-4 mRNA expression, has previously been found after in vitro stimulation with $\mathrm{GAD}_{65}$ peptides in healthy, high-risk, first-degree relatives of patients with type 1 diabetes (28), indicating that this pattern has a protective role in the development of type 1 diabetes.

An immune-modulating effect by photopheresis could also be demonstrated after in vitro stimulation with insulin, which caused an inhibition of the cytokine response. Expression of Th1-associated IFN- $\gamma$ mRNA decreased during treatment, implying a shift in favor of Th2. Deviation of the immune system toward Th2-like immunity after in vitro stimulation with insulin has been suggested to have an immunosuppressive effect in healthy, high-risk individuals (28). However, cytokine response by insulin at the level of translation into protein was very low. In fact, several recent studies have failed to detect any T-cell proliferation against insulin or insulin peptides in both diabetic and prediabetic patients (39-41). We have also previously reported about the phenomenon of a low IFN- $\gamma$ response against insulin in both high-risk individuals and in children newly diagnosed with diabetes, in comparison with other antigens e.g., the $\mathrm{GAD}_{65}$ peptide (28).

The mitogen PHA induced increased expression and secretion of both IFN- $\gamma$ and IL-4 in all children studied. Expression of IFN- $\gamma$ and IL-4 mRNA and also secretion of IL-10 did, however, decrease during the period of photopheresis treatment. Changes in cytokine response to PHA have also been observed in PBMCs from patients treated with photopheresis

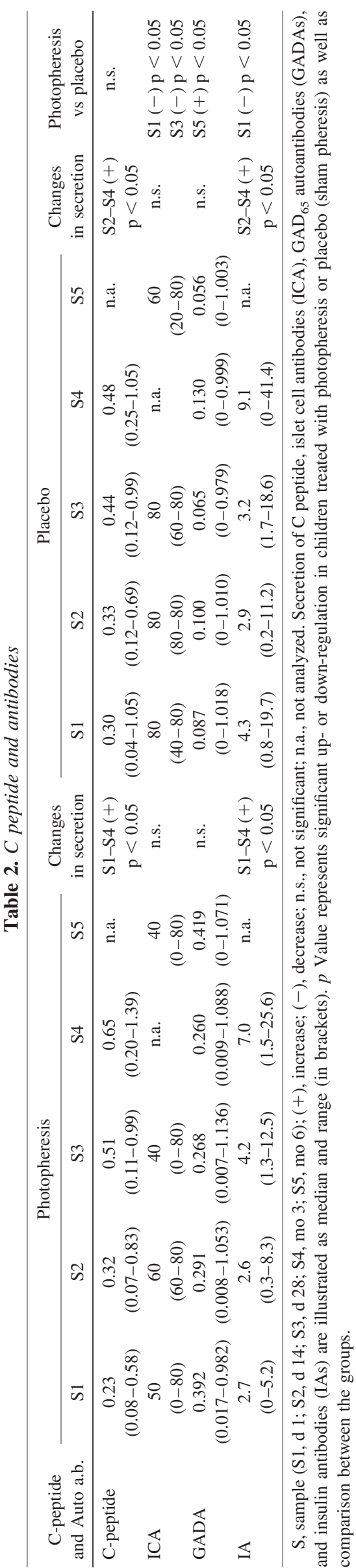


after heart transplantation (42). Secretion of IL-4 was found to increase, reaching a peak soon after initial treatment. IL-4 then progressively decreased together with decreased secretion of IFN- $\gamma$ and IL-2 during continuous treatment with photopheresis (42). In contrast, KHL did not cause any pronounced immune response in PBMCs from children with type 1 diabetes, which indicates a selective and specific response of diabetes-associated antigens.

No differences in humoral or cellular response to BSA have been observed between patients newly diagnosed with diabetes and healthy adults $(43,44)$. Treatment with photopheresis had no clear influence on mononuclear cells after in vitro stimulation with ABBOS, which is in agreement with our previous findings showing a modest increase in IFN- $\gamma$ and IL-4 mRNA expression from ABBOS in both children with diabetes and healthy children (29). It is possible that the lack of response to this peptide can be influenced by the uptake of BSA and also the ABBOS peptide from FCS during cryopreservation.

We observed, not on an individual basis but in the group of children type 1 diabetes treated with photopheresis, a change mainly toward a Th2-like profile. These findings strengthen the importance of this kind of treatment, which obviously can affect the immune system. However, our treatment comes late in the disease process, when most of the $\beta$-cell function already is lost. Although our results clearly indicate an effect on autoreactive cytokine-secreting cells, the precise mechanisms for induction of this response are unknown. $\mathrm{C}$ peptide increased during the treatment period in all children regardless of treatment. Thus, we cannot show that the positive effect by photopheresis on $\beta$-cell function reported earlier (24) depends on the identified changes in immune balance.

The previously reported slight clinical effects and the immunological effects reported here correspond to the fact that only a minority of leukocytes are directly affected during each photopheresis procedure. It has previously been shown that reinfused treated cells stimulate an autologous suppressor response toward $\mathrm{T}$ cells of similar clones not reached by active photopheresis treatment (45), suggesting that resident cells are affected indirectly. This could be one reason why the immunological effect is seen after repeated treatments and especially during partial remission. Another possible mechanism would be that tolerized autoreactive $\mathrm{T}$ cells by bystander activation e.g., in the target organ or in adjacent lymph nodes could induce down-regulating cytokines like IL-4, IL-10, and transforming growth factor $\beta$ (46). Although speculative, another tempting explanation would be the induction of immune regulatory populations, as has been described in experimental models of autoimmunity (47).

In summary, our results show that photopheresis seems to have an immune-modulating effect on Th1/Th2-like cytokines, inducing a Th2-like shift in the response against a $\mathrm{GAD}_{65}$ peptide and insulin. Thus, treatment with photopheresis may act as an immunological modifier that can regulate a Th1/Th2-like imbalance toward normalization. This sheds light on the thus far obscure immunological effect of photopheresis treatment.

Acknowledgments. The laboratory work was performed at the Clinical Research Centre of the Faculty of Health Sciences.
We gratefully acknowledge Lena Berglert, Sonja Hellström, Maria Olofson, Berit Svensson-Waldner, and Mikael Tiger for their skillful technical assistance.

\section{REFERENCES}

1. Katz JD, Benoist C, Mathis D 1995 T helper cell subsets in insulin-dependent diabetes. Science 268:1185-1188

2. Del Prete GF, De Carli, M, Mastromauro C, Biagiotti R, Macchia D, Falagiani P, Ricci M, Romagnani S 1991 Purified protein derivative of Mycobacterium tuberculosis and excretory-secretory antigen(s) of Toxocara canis expand in vitro human $\mathrm{T}$ cells with stable and opposite (type $1 \mathrm{~T}$ helper or type $2 \mathrm{~T}$ helper) profile of cytokine production. J Clin Invest 88:346-350

3. Romagnani S 1994 Lymphokine production by human T cells in disease states. Annu Rev Immunol 12:227-257

4. Foulis AK, McGill M, Farquharson MA 1991 Insulitis in type 1 (insulin-dependent) diabetes mellitus in man - macrophages, lymphocytes, and interferon- $\gamma$ containing cells. J Pathol 165:97-103

5. Simon AK, Seipelt E, Sieper J 1994 Divergent T-cell cytokine patterns in inflammatory arthritis. Proc Natl Acad Sci U S A 91:8562-8566

6. Troutt AB, Kelso A 1992 Enumeration of lymphokine mRNA-containing cells in vivo in a murine graft-versus-host reaction using the PCR. Proc Natl Acad Sci U S A 89:5276-5280

7. McKenzie GJ, Emson CL, Bell SE, Anderson S, Fallon P, Zurawski G, Murray R, Grencis R, McKenzie AN 1998 Impaired development of Th2 cells in IL-13-deficient mice. Immunity 9:423-432

8. Zurawski G, de Vries JE 1994 Interleukin 13, an interleukin 4-like cytokine that acts on monocytes and B cells, but not on T cells. Immunol Today 15:19-26

9. Fiorentino DF, Bond MW, Mosmann TR 1989 Two types of mouse T helper cell. IV. Th2 clones secrete a factor that inhibits cytokine production by Th1 clones. J Exp Med 170:2081-2095

10. Rabinovitch A 1994 Immunoregulatory and cytokine imbalances in the pathogenesis of IDDM. Therapeutic intervention by immunostimulation? Diabetes 43:613-621

11. Liblau RS, Singer SM, McDevitt HO 1995 Th1 and Th2 CD4+ T cells in the pathogenesis of organ-specific autoimmune diseases. Immunol Today 16:34-38

12. Russell-Jones R 2001 Shedding light on photopheresis. Lancet 357:820-821

13. Edelson RL, Berger CL, Gasparro FP, Jegasothy B, Heald P, Wintroub B, Vanderheid E, Knobler R, Wolff K, Plewig G, McKiernan G, Christiansen I, Oster M, Honingsmann H, Wilford H, Kokoschka E, Rehle T, Perez M, Stingl G, Laroche L 1987 Treatment of cutaneous T-cell lymphoma by extracorporeal photochemotherapy. N Engl J Med 316:297-303

14. Zouboulis CC, Schmuth M, Doepfmer S, Dippel E, Orfanos CE 1998 Extracorporeal photopheresis of cutaneous T-cell lymphoma is associated with reduction of peripheral CD4 + T lymphocytes. Dermatology 196:305-308

15. Greinix HT, Volc-Platzer B, Rabitsch W, Gmeinhart B, Guevara-Pineda C, Kalhs P, Krutmann J, Hönigsmann H, Ciovica M, Knobler RM 1998 Successful use of extracorporeal photochemotherapy in the treatment of severe acute and chronic graft-versus-host disease. Blood 92:3098-3104

16. Barr ML, Meiser BM, Eisen HJ, Roberts RF, Livi U, Dall'Amico R, Dorent R, Rogers JG, Radovancevic B, Taylor DO, Jeevanandam V, Marboe CC 1998 Photopheresis for the prevention of rejection in cardiac transplantation. N Engl J Med 339:17441751

17. Malawista SE, Trock DH, Edelson RL 1991 Treatment of rheumatoid arthritis by extracorporeal photochemotherapy. A pilot study. Arthritis Rheum 34:646-654

18. Knobler RM, Graninger W, Graninger W, Lindmaier A, Trautinger F, Smolen JS 1992 Extracorporeal photochemotherapy for the treatment of systemic lupus erythematosus. A pilot study. Arthritis Rheum 35:319-323.

19. Vahlquist C, Larsson M, Ernerudh J, Berlin G, Skogh T, Vahlquist A 1996 Treatment of psoriatic arthritis with extracorporeal photochemotherapy and conventional psoralen-ultraviolet A irradiation. Arthritis Rheum 39:1519-1523

20. Gasparro FP, Dall'Amico R, Goldminz D, Simmons E, Weingold D 1989 Molecular aspects of extracorporeal photochemotherapy. Yale J Biol Med 62:579-593

21. Laskin JD, Lee E, Yurkow EJ, Laskin DL, Gallo MA 1985 A possible mechanism of psoralen phototoxicity not involving direct interaction with DNA. Proc Natl Acad Sci U S A 82:6158-6162

22. Alcindor T, Gorgun G, Miller KB, Roberts TF, Sprague K, Schenkein DP, Foss FM 2001 Immunomodulatory effects of extracorporeal photochemotherapy in patients with extensive chronic graft-versus-host disease. Blood 98:1622-1625

23. Girardi M, Schechner J, Glusac E, Berger C, Edelson R 2002 Transimmunization and the evolution of extracorporeal photochemotherapy. Transfus Apheresis Sci 26:181190

24. Ludvigsson J, Samuelsson U, Ernerudh J, Johansson C, Stenhammar L, Berlin G 2001 Photopheresis at onset of type 1 diabetes: a randomized, double-blind, placebocontrolled trial. Arch Dis Child 85:149-154

25. Puglisi C, deSilva A, Meyer J 1977 Determination of 8-methoxypsoralen, a photoactive compound, in blood by high pressure liquid chromatography. Anal Lett 10:39-50

26. Cheung R, Karjalainen J, Vandermeulen J, Singal DP, Dosch HM 1994 T cells from children with IDDM are sensitized to bovine serum albumin. Scand J Immunol 40:623-628

27. Karlsson MG, Ludvigsson J 2000 The ABBOS-peptide from bovine serum albumin causes an IFN- $\gamma$ and IL-4 mRNA response in lymphocytes from children with recent onset of type 1 diabetes. Diabetes Res Clin Pract 47:199-207 
28. Karlsson MG, Lawesson SS, Ludvigsson J 2000 Th1-like dominance in high-risk first-degree relatives of type 1 diabetic patients. Diabetologia 43:742-749

29. Karlsson MG, Garcia J, Ludvigsson J 2001 Cow's milk proteins cause similar Th1and Th2-like immune response in diabetic and healthy children. Diabetologia 44:1140-1147

30. Janefjord CK, Jenmalm MC 2001 PHA-induced IL-12R beta(2) mRNA expression in atopic and non-atopic children. Clin Exp Allergy 31:1493-1500

31. Heding LG 1975 Radioimmunological determination of human C-peptide in serum. Diabetologia 11:541-548

32. Ludvigsson J, Heding LG. 1976 C-peptide in children with juvenile diabetes. A preliminary report. Diabetologia 12:627-630

33. Bottazzo GF, Florin-Christensen A, Doniach D 1974 Islet-cell antibodies in diabetes mellitus with autoimmune polyendocrine deficiencies. Lancet 2:1279-1283

34. Grubin CE, Daniels T, Toivola B, Landin-Olsson M, Hagopian WA, Li L, Karlsen AE, Boel E, Michelsen B, Lernmark A 1994 A novel radioligand binding assay to determine diagnostic accuracy of isoform-specific glutamic acid decarboxylase antibodies in childhood IDDM. Diabetologia 37:344-350

35. Petersen JS, Hejnaes KR, Moody A, Karlsen AE, Marshall MO, Høier-Madsen M, Boel E, Michelsen BK, Dyrberg T 1994 Detection of GAD65 antibodies in diabetes and other autoimmune diseases using a simple radioligand assay. Diabetes 43:459467

36. Falorni A, Örtqvist E, Persson B, Lernmark A 1995 Radioimmunoassays for glutamic acid decarboxylase (GAD65) and GAD65 autoantibodies using 35S or 3H recombinant human ligands. J Immunol Methods 186:89-99

37. Palmer JP, Asplin CM, Clemons P, Lyen K, Tatpati O, Raghu PK, Paquette TL 1983 Insulin antibodies in insulin-dependent diabetics before insulin treatment. Science 222:1337-1339
38. Harrison LC, Chu SX, DeAizpurua HJ, Graham M, Honeyman MC, Cloman PG 1992 Islet-reactive T-cells are a marker of preclinical insulin-dependent diabetes. J Clin Invest 89:1161-1165

39. Durinovic-Belló I, Hummel M, Ziegler AG 1996 Cellular immune response to diverse islet cell antigens in IDDM. Diabetes 45:795-800

40. Schloot NC, Roep BO, Wegmann D, Yu L, Chase HP, Wang T, Eisenbarth GS 1997 Altered immune response to insulin in newly diagnosed compared to insulin-treated diabetic patients and healthy control subjects. Diabetologia 40:564-572

41. Maccherini M, Diciolla F, Laghi Pasini F, Lisi G, Tanganelli P, D'Ascenzo G, Mondillo S, Carone E, Oricchio L, Baraldi C, Capecchi PL, Lazzerini PE, Toscano T, Barretta A, Giunti G, Schuerfeld K, Fimiani M, Papalia U 2001 Photopheresis immunomodulation after heart transplantation. Transplant Proc 33:1591-1594

42. Atkinson MA, Bowman MA, Kao KJ, Campbell L, Dush PJ, Shah SC, Simell O, Maclaren NK 1993 Lack of immune responsiveness to bovine serum albumin in insulin-dependent diabetes. N Engl J Med 329:1853-1858

43. Vaarala O, Klemetti P, Savilahti E, Reijonen H, Ilonen J, Åkerblom HK 1996 Cellular immune response to cow's milk beta-lactoglobulin in patients with newly diagnosed IDDM. Diabetes 45:178-182

44. Wolfe JT, Lessin SR, Singh AH, Rook AH 1994 Review of immunomodulation by photopheresis: treatment of cutaneous T-cell lymphoma, autoimmune disease, and allograft rejection. Artif Organs 18:888-897

45. Steinmann L 1996 A few autoreactive cells in an autoimmune infiltrate control a vast population of nonspecific cells: a tale of smart bombs and the infantry. Proc Natl Acad Sci U S A 93:2253-2256

46. Sakaguchi S 2000 Regulatory T cells: key controllers of immunologic self-tolerance. Cell 101:455-458 